\title{
Novel Indole Derivative as the First P-glycoprotein Inhibitor from the Skin of Indian Toad (Bufo melanostictus)
}

\author{
P-glikoprotein İnhibitörü Olarak Hint Kurbağası (Bufo melanostictus) \\ Derisinden Illk Kez Elde Edilen Yeni Bir İndol Türevi
}

\author{
(D) Prasad NEERATI*, (D) Sangeethkumar MUNIGADAPA \\ Kakatiya University College of Pharmaceutical Sciences, Department of Pharmacology, Division of Drug Metabolism and Pharmacokinetics, Telangana, \\ India
}

\section{ABSTRACT}

Objectives: To study the inhibitory effect of novel indole derivative (NID) from Indian toad skin (Bufo melanostictus) on permeability glycoprotein (P-gp).

Materials and Methods: Dried Indian toad skin was used to isolate NID with column chromatography, and its structure was elucidated by infrared spectra, ${ }^{13} \mathrm{C}$ nuclear magnetic resonance (NMR), ${ }^{1} \mathrm{H}$ NMR spectra, and liquid chromatography-mass spectrometry. Female Wistar rats were used to determine $\mathrm{LD}_{50}$, in vitro permeability studies were done with the intestinal sac method, and in vivo pharmacokinetic studies were carried out to prove the P-gp inhibition using the rat model.

Results: The NID has shown increased clear permeability $P_{\text {app }}\left(x 10^{-6} \mathrm{~cm} / \mathrm{sec}\right)$ significantly $(p<0.001)$ from $1.04 \pm 0.11$ to $2.90 \pm 0.08$ in ileum $1.44 \pm 0.14$ to $3.92 \pm 0.13$ in jejunum this in vitro results confirmed that P-gp inhibited, this was further confirmed by in vivo studies in in vivo studies observed increased oral bioavailability of digoxin (DIG) significantly in NID treated groups from $3.26 \pm 0.25$ to $7.47 \pm 0.18 \mathrm{ng} / \mathrm{mL}$, the volume of distribution decreased from $232.56 \pm 64.59$ to $86.57 \pm 7.04 \mathrm{~L} / \mathrm{kg}$. Area under the curve increased from $37.89 \pm 1.13$ to $64.62 \pm 0.70 \mathrm{ng} / \mathrm{mL} / \mathrm{hr}$. This demonstrates NID increased the oral bioavailability of DIG significantly.

Conclusion: Many compounds were isolated from the Indian toad skin. This NID was not reported earlier. Results demonstrate NID increased the oral bioavailability of DIG significantly. The isolated NID from Indian toad skin proved as a potent P-gp inhibitor in both in vitro and in vivo studies, and further studies are needed to develop as a possible new drug candidate.

Key words: Clear permeability, bioavailability, novel indole derivative, permeability glycoprotein

öz

Amaç: Hint kurbağa derisinden (Bufo melanostictus) elde edilen yeni indol türevinin (NID) permeabilite glikoproteini (P-gp) üzerindeki inhibitör etkisini incelemek.

Gereç ve Yöntemler: NID, kurutulmuș Hint kurbağası derisinden kolon kromatografisi ile elde edilmiș ve yapı tayini infrared spektoskopisi, ${ }^{13} \mathrm{C}$ nükleer magnetic rezonans (NMR), 'H NMR spektroskopisi ve sıvı kromatografisi-kütle spektrometrisi ile gerçekleștirilmiștir. $\mathrm{LD}_{50}$, diși Witsar sıçanlar kullanılarak belirlenmiştir, in vitro permeabilite çalışmaları intestinal kese yöntemi ile, ve P-gp inhibisyonunu doğrulamak amacıyla in vivo farmakokinetik çalıșmalar, rat modeli kullanılarak gerçekleștirilmiştir.

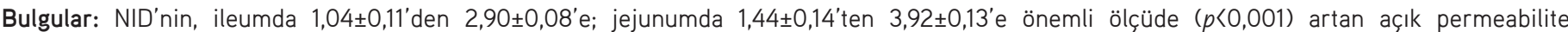
göstermiștir $\mathrm{P}_{\text {app }}\left(\times 10^{-6} \mathrm{~cm} / \mathrm{s}\right)$ anlamlı bir şekilde göstermiştir ve bu in vitro sonuçlar P-gp'nin inhibe edildiğini doğrulamaktadır; bu sonuçlar NID

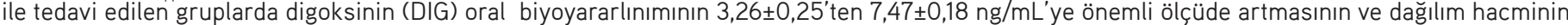
$232,56 \pm 64,59$ 'dan $86,57 \pm 7,04$ L/kg'ye düșmesinin gözlenmesi ile in vivo olarak da doğrulanmıștır. Eğrinin altındaki alan $37,89 \pm 1,13^{\prime}$ ten $64,62 \pm 0,70$ $\mathrm{ng} / \mathrm{mL} /$ saate yükselmiştir. Bu, NID'nin DIG'nin oral biyoyararlanımını önemli ölçüde artırdığını gösterir. 
Sonuç: Hint kurbağa derisinden birçok bileşik izole edilmiştir. NID bileşiği daha önce bildirilmemiştir. Sonuçlar, NID'nin DIG'nin oral biyoyararlanımını önemli ölçüde artırdığını göstermektedir. Hint kurbağa derisinden izole edilen NID'nin hem in vitro hem de in vivo çalıșmalarda güçlü bir P-gp inhibitörü olduğu kanıtlanmıştır ve olası yeni bir ilaç adayı olarak geliștirmek için daha fazla çalışmaya intiyaç vardır.

Anahtar kelimeler: Açık permeabilite, biyoyararlınım, yeni indol türevi, permeabilite glikoprotein

\section{INTRODUCTION}

Toxic animals are widely distributed throughout the globe.,2 Venomous animals are recognized as a new emerging source of new drug discovery and therapeutics. ${ }^{3}$ Recently many new bioactive compounds from different toads were reported. ${ }^{4}$ Toads belong to amphibians and Anura family. The toad skin and parotid glands play an essential role in the survival of amphibians from diverse conditions and predators. 5,6 Toads possess two types of glands beneath their skin, mucous glands and granular glands. Mucous glands secrete thick mucus secretions, which are important to keep toad skin moist. ${ }^{7}$ Granular glands secrete acrid, toxic substances, which provides protection from predators. ${ }^{8}$ This acrid, toxic substance, when comes intact, induces inflammation, irritation, and vomiting sensations in toad predators. ${ }^{9}$ This glandular secretion chemically belongs to potent substances like steroids, alkaloids, peptides, proteins, and biogenic amines. ${ }^{10}$ New drug discovery is a challenge many active compounds extracted from plants, animals, fungi, other sources. There is still to discover new compounds from the above sources. ${ }^{11}$ Toad skin extracts have been widely used for treating many types of ailments in China and other countries as traditional alternative medicine. The chemical composition and pharmacological activities of toad skin remain unclear.12 Permeability glycoprotein ( $P$-gp) is an important transporting protein present on the cell membrane that effluxes many xenobiotic substances like drug molecules out of cells. ${ }^{13}$ P-gp has a significant impact on drug absorption, distribution, metabolism, excretion and is associated with drugdrug interactions. ${ }^{14-16} \mathrm{P}$-gp is over-expressed on the surface of cancer cells and prevents drug entry into the tumor due to rapid and prolonged efflux mechanism. ${ }^{17,18} \mathrm{P}$-gp induces resistance to anticancer drugs, which leads to therapeutic failure. There are many phytochemicals and drugs reported as P-gp inhibitors but associated with severe side effects. ${ }^{19,20}$ An alternate approach is needed to overcome this issue by exploring new compounds from new sources, ${ }^{21,22}$ in this study toad skin extract studies for inhibitory action on P-gp. In this study, digoxin (DIG) was used as probe substrate, ${ }^{23}$ and verapamil (VER) ${ }^{24}$ was taken as standard inhibitor. The isolated novel indole derivative (NID) inhibited P-gp and enhanced the oral bioavailability of DIG in vivo studies.

\section{MATERIALS AND METHODS}

\section{Experimental}

\section{Sample collection and preparation}

Adult live toads ( 45 to $50 \mathrm{~g}$ ) were collected from the near places in Warangal and University surroundings. After collecting the toads, the skins were isolated carefully and shade dried at room temperature $\left(27^{\circ} \mathrm{C}\right)$; after complete dryness soaked in methanol for 30 days in an ambercolored bottle, the supernatant was collected, evaporated to dryness using rotary evaporator, at the end, dark brown solid mass methanolic extract $(44 \mathrm{~g})$ was obtained. The methanol extract was extracted further with ethyl acetate; this ethyl acetate fraction (EAF) was collected. EAF was subjected to column chromatography on silica gel (100-200 mesh-Merck), eluted slowly in increasing polarity mixture of solvents like $n$-hexane, chloroform, ethyl acetate, ethanol, methanol, and water to obtain different fractions. five fractions were collected; fraction-2 was obtained as a pale gray colored compound, which on TLC produced a single spot. Further purification was done with acetone and methanol.25,26 The final isolated compound yield was found to be $800 \mathrm{mg}$.

\section{Animals}

Female and male Wistar rats were procured from Vyas Enterprises, Hyderabad, acclimatized for 10 days, then used housed in standard laboratory conditions. ${ }^{27}$ All experimental animal protocols were approved by the Ethics Committee of IAEC (approval number: IAEC/02/UCPSc/KU/2016).

\section{Chemicals and other requirements}

Acetonitrile (Merck-Mumbai), methanol (Merck-Mumbai), EA (Merck-Mumbai), DIG (Sigma Aldrich-Bangalore), VER (Lupin Pvt Labs-Pune-India) Equipment used are, n-hexane (MerckMumbai), chloroform (Merck- Mumbai), ethanol (MerckMumbai), high-performance liquid chromatography (HPLC) (Schimadzu, with phenominex C-18 column), biofugecentrifuge (Heraeus instrument- Germany), chromatography column-borosilicate made, TLC aluminum Plates-Sigma Aldrich, ultra sonicator (Ramsit scientific equipementHyd), rotavapor-R-300 (Mumbai-India), oral feeding needle, syringe filters-minisart (sartorius stedim Biotech-Germany).

\section{Toxicity studies}

According to the OECD-423 guidelines maximum, tolerated dose (MTD) was determined using 15 female Wistar rats. Rats were divided into 5 groups $(n=3)$, control group treated with normal saline, the second group given NID ( $5 \mathrm{mg} / \mathrm{kg}$, p.o.), third group NID (50 mg/kg, p.o.), the fourth group NID (300 mg/kg, p.o.), fifth group NID (2000 mg/kg, p.o.). Toxic effects were recorded for 14 days during the period observed for mortality, physiological parameters like body weight changes, food intake, water intake, and behavioral changes in each animal noted. ${ }^{28}$

\section{Characterization of NID using spectral data}

Spectral analysis was done using liquid chromatography-mass spectrometry (LC-MS) analysis 2.6.1. The components were identified using mass spectral libraries The ${ }^{1} \mathrm{H}$ spectra were 
recorded at $300 \mathrm{~K}$ on a spectrometer operating at $600.13 \mathrm{MHz}$ (14.1 T) using a $5 \mathrm{~mm}$ inverse probe equipped with a z-shielded gradient. Nuclear magnetic resonance (NMR) samples were prepared by dissolving extract in $500 \mu \mathrm{L}$ dimethyl sulfoxide and $1 \mu \mathrm{L}$ dimethyl formamide as an internal standard. ${ }^{13} \mathrm{C}$ NMR spectral reports were made by comparison of the observed chemical shift values with the reported values. An infrared (IR) spectrophotometer is used, and spectral data is used to find functional groups. ChemDraw pro 8.0 (Perkin Elmer) was used for structure assessment.

\section{In vitro studies}

Intestinal sac study was conducted according to the previously described methods. ${ }^{29}$ Rats were grouped and sacrificed using anesthetic ether; the intestine was surgically removed, flushed with 50-mL saline (5\%). The small intestine was cut into two segments jejunum and ileum of equal length $(5 \mathrm{~cm})$. The probe drug (DIG $500 \mu \mathrm{g} / \mathrm{mL}$ ) was dissolved in $\mathrm{pH} 7.4$ isotonic Dulbecco's phosphate buffered saline (D-PBS) containing 25 $\mathrm{mM}$ glucose. Similarly, DIG + VER $(100 \mu \mathrm{g} / \mathrm{mL}), \mathrm{DIG}+\mathrm{NID} 2$ $\mathrm{mg} / \mathrm{mL}$ and DIG + NID $4 \mathrm{mg} / \mathrm{mL}$ loaded. And both ends of the sac were ligated tightly with surgical sutures. The sacs were placed in a beaker containing $40 \mathrm{~mL}$ of D-PBS, containing 25 $\mathrm{mM}$ glucose. The medium was pre-warmed at $37^{\circ} \mathrm{C}$ and preoxygenated with $5 \% \mathrm{CO}_{2} / 95 \% \mathrm{O}_{2}$ under bubbling with mixture gas, the transport of the DIG from apical to basolateral and basolateral to apical samples was collected periodically for 120 min periodically, the collected samples were stored at $-20^{\circ} \mathrm{C}$ until analysis. The samples were analyzed by HPLC.

\section{Calculation of clear permeability coefficient}

The clear permeability coefficient $\left(P_{\text {app }}\right)$ of DIG was calculated from the following equation:

Where $d Q / d t$ : Transport rate of the drug in the serosal medium, $A$ : is the surface area of the intestinal sacs, and $C^{\circ}$ : Initial concentration inside the sacs. ${ }^{30}$

\section{Sample preparation for intestinal sac sample analysis}

Samples were extracted using a simple protein precipitation method by adding acetonitrile $(200 \mu \mathrm{L})$ to samples $(100 \mu \mathrm{L})$. Samples were vortexed for $10 \mathrm{~min}$ and centrifuged at 6,000 rpm for $15 \mathrm{~min}$. The resultant clean supernatant $(20 \mu \mathrm{L})$ was injected and analyzed using HPLC (Supplementary Figure 1). The mobile phase consists of acetonitrile: Water 65:35. Flow rate: $1 \mathrm{~mL} / \mathrm{min}$, pressure: $115 \mathrm{~kg} . \mathrm{f} / \mathrm{cm}^{2}$, ultraviolet-detection at the following: $220 \mathrm{~nm}$.

\section{In vivo studies}

Male Wistar rats were used kept one week for acclimatization during the period supplied with normal ad libitum and free access for water. After one week they were divided into 4 groups $(n=6)$ the first group treated with DIG $(0.5 \mathrm{mg} / \mathrm{kg}$, p.o.). Second group treated with DIG $(0.5 \mathrm{mg} / \mathrm{kg}, p .0)+.\mathrm{VER}(2 \mathrm{mg} /$ $\mathrm{kg}$, p.o.), third group treated with DIG $(0.5 \mathrm{mg} / \mathrm{kg}$, p.o. $)+\mathrm{NID}$ ( $2 \mathrm{mg} / \mathrm{kg}$, p.o.) fourth group DIG $(0.5 \mathrm{mg} / \mathrm{kg}$, p.o.) + NID (4 mg/ kg.p.o). Blood sample were collected by picturing lateral tail vein $^{31}$ at $0,0.5,1,2,4,6,8,12$ and $24 \mathrm{~h}$ time points. Samples were centrifuged and supernatant extracted with acetonitrile precipitation methods Samples were stored at $-4^{\circ} \mathrm{C}$ until used for analyzed by HPLC (Supplementary Figure 2). ${ }^{32}$

\section{Statistical analysis}

All the pharmacokinetic parameters were analyzed using Phoenix WinNonlin version 8.3 kinetic software. The statistical analysis was performed using One-Way ANOVA followed by Bonferroni post-test and Graph Pad Prism version (8.0.2).

\section{RESULTS}

\section{Structure assessment using spectral analysis}

Based on the spectral analysis using LC-MS (Supplementary Figure 3), ${ }^{1} \mathrm{H}$ NMR (Supplementary Figure 4) (Table 1) ${ }^{13} \mathrm{C}$ NMR (Supplementary Figure 5) IR spectra (Supplementary Figure 6) and values the structure of NID is elucidated (Figure 1).

\section{Toxicity assessment and determination of MTD}

The mortality was found in three animals at $50 \mathrm{mg} / \mathrm{kg}$ treated groups, according to OECD-423 guidelines, comes under category-2,,3 (LD 50 cut-off dose $25 \mathrm{mg} / \mathrm{kg}$ ). At $5 \mathrm{mg} / \mathrm{kg}$, the animals remained alive after the administration of NID. Body weight slightly decreased in NID $5 \mathrm{mg} / \mathrm{kg}$, compared to control. Water intakes decreased somewhat in NIA $5 \mathrm{mg} / \mathrm{kg}$, compared to control, and locomotor activity was not changed significantly (Figure 2A-D) (Supplementary Table 1). The MTD found to be $25 \mathrm{mg} / \mathrm{kg}$

\section{In vitro studies}

The $\mathrm{P}_{\text {app }}\left(\mathrm{x} 10^{-6} \mathrm{~cm} / \mathrm{sec}\right)$ significantly increased $(p<0.001)$ in NID treated groups from $1.04 \pm 0.11$ to $2.90 \pm 0.08$ in ileum, and

\begin{tabular}{|c|c|c|c|}
\hline $\mathrm{H}^{1}$ & $\delta p p m$ & $\mathrm{C}^{13}$ & $\delta c t p p m$ \\
\hline 1 & $5.5(\mathrm{~S} . \mathrm{H})$ & 1 & - \\
\hline 2 & $6.92(\mathrm{~S} . \mathrm{H})$ & 2 & 119 \\
\hline 3 & - & 3 & 120 \\
\hline 4 & 6.9 (S.H) & 4 & 111 \\
\hline 5 & $5.5(\mathrm{~S} . \mathrm{H})$ & 5 & 151 \\
\hline 6 & $2.6(\mathrm{~S} . \mathrm{H})$ & 6 & 107 \\
\hline 7 & $6.9(\mathrm{~S} . \mathrm{H})$ & 7 & 125 \\
\hline 8 & $2.15(\delta 3 \mathrm{H}, \mathrm{J}=7.4 \mathrm{HZ})$ & 8 & 123 \\
\hline 9 & $2.4(\delta 3 \mathrm{H}, J=7.2 \mathrm{HZ})$ & 9 & 129 \\
\hline 10 & - & 10 & 103 \\
\hline 11 & $2.6(\mathrm{~S}, 3 \mathrm{H})$ & 11 & 15 \\
\hline 12 & $2.9(\mathrm{~S} .3 \mathrm{H})$ & 12 & 66 \\
\hline & - & 13 & 24 \\
\hline & - & 14 & 47 \\
\hline
\end{tabular}

NMR: Nuclear magnetic resonance, NID: Novel indole derivative, $\mathrm{CDCl}_{3}$ : Deuterated chloroform 
$1.44 \pm 0.14$ to $3.92 \pm 0.13$ in jejunum compare to control group (Table 2) (Supplementary Figure 1).

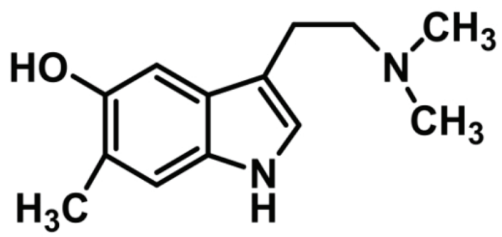

Figure 1. Chemical structure of NID

NID: Novel indole derivative

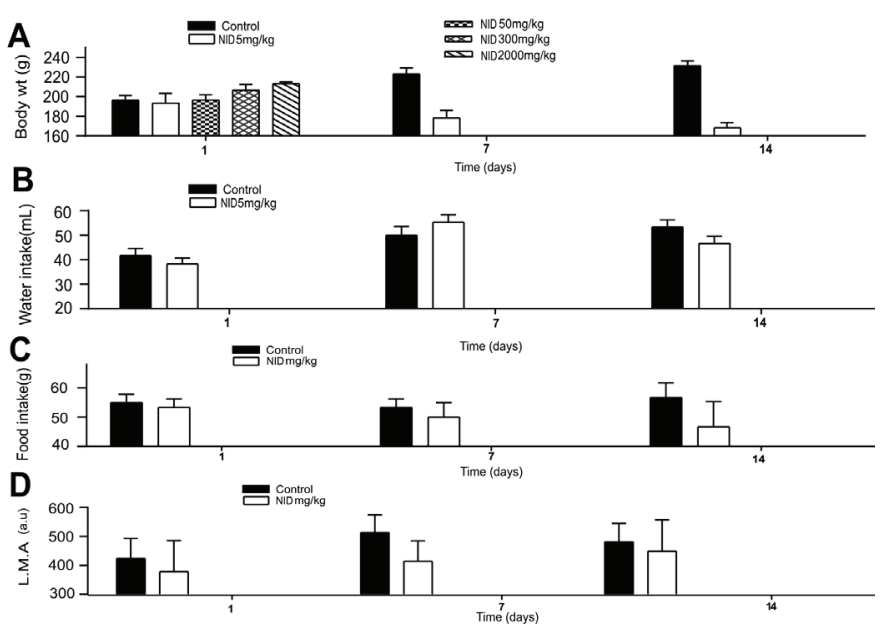

Figure 2. Toxicity studies of NID. NID: Novel indole derivative, A: Body weight, B: Food intake, C: Water intake, D: Locomotor activity

\section{In vivo studies}

The plasma drug concentration of DIG significantly increased in NID treated groups compared to control and positive control groups (Figure 3) (Supplementary Table 2). $C_{\max }$ increased from $3.26 \pm 0.254$ to $7.47 \pm 0.186 \mathrm{ng} / \mathrm{mL}, T_{\max }$ decreased from $27.17 \pm 13.85$ to $9.88 \pm 1.13 \mathrm{~h}, \mathrm{AUMC}$ from $371.27 \pm 18.16$ to $530.57 \pm 16.52 \mathrm{ng} . \mathrm{h}^{2} / \mathrm{mL}$, area under the curve increased from $37.89 \pm 1.132$ to $64.62 \pm 0.70$ $\mathrm{ng} . \mathrm{h}^{2} / \mathrm{mL}$, CL from $6.09 \pm 0.24$ to $7.87 \pm 0.22 \mathrm{~L} / \mathrm{h} / \mathrm{kg}$, volume of distribution decreased from $232.56 \pm 64.59$ to $86.57 \pm 7.049 \mathrm{~L} / \mathrm{kg}$, mean residual time from $9.79 \pm 0.27$ to $8.20 \pm 0.19$ h significantly ( $p<0.001)$ (Table 3).

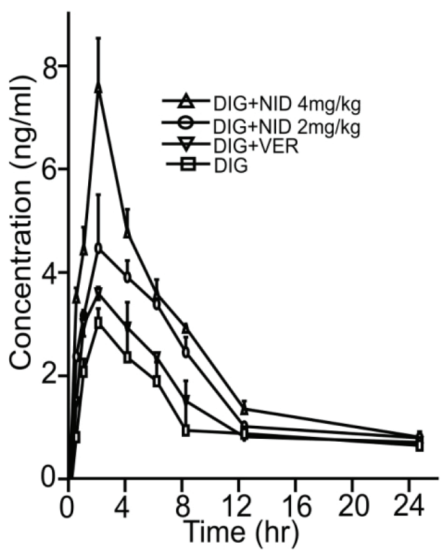

Figure 3. Effect novel indole derivative on pharmacokinetics of digoxin. Values mentioned in mean $\pm \mathrm{SD}(n=6)$. NID: Novel indole derivative, DIG: Digoxin, VER: Verapamil, SD: Standard deviation

\section{Table 2. In vitro clear permeability studies}

\begin{tabular}{lllll} 
Clear permeability & DIG & DIG + VER & DIG + NID $2 \mathrm{mg} / \mathrm{mL}$ & DIG + NID $4 \mathrm{mg} / \mathrm{mL}$ \\
\hline Ileum & $1.04 \pm 0.11$ & $1.77 \pm 0.09^{\star *}$ & $2.42 \pm 0.12^{* *}$ & $2.90 \pm 0.08^{\star *}$ \\
\hline Jejunum & $1.44 \pm 0.14$ & $2.00 \pm 0.17^{* *}$ & $2.45 \pm 0.13^{* *}$ & $3.92 \pm 0.13^{* * *}$ \\
\hline
\end{tabular}

Data represent mean \pm SD values, One-Way ANOVA was used for statistical analysis, ${ }^{* *} p<0.01,{ }^{* * *} p<0.001$ compared with the control (DIG). DIG: Digoxin, VER: Verapamil, NID: Novel indole derivative

Table 3. Effect of NID on pharmacokinetic parameters of digoxin

\begin{tabular}{|c|c|c|c|c|}
\hline Pk parameter & DIG & DIG + VER & DIG + NID 2 mg/kg & DIG + NID $4 \mathrm{mg} / \mathrm{kg}$ \\
\hline $\mathrm{C}_{\max }(\mathrm{ng} / \mathrm{mL})$ & $3.26 \pm 0.254$ & $3.79 \pm 0.117^{\star \star \star}$ & $4.59 \pm 0.097^{\star * \star *}$ & $7.47 \pm 0.186^{\star \star \star \star}$ \\
\hline $\mathrm{T}_{\max }(\mathrm{hr})$ & $27.17 \pm 13.85$ & $12.512 \pm 0.447^{\star \star}$ & $10.70 \pm 0.430^{\star \star *}$ & $9.88 \pm 1.137^{\star \star \star}$ \\
\hline AUMC (ng.h²/mL) & $371.27 \pm 18.16$ & $398.61 \pm 9.00$ * & $468.92 \pm 13.79^{* * * *}$ & $530.57 \pm 16.52^{* * * *}$ \\
\hline$A \cup C_{0-t}(\mathrm{ng} / \mathrm{mL} / \mathrm{hr})$ & $37.89 \pm 1.132$ & $43.01 \pm 0.43^{* \star \star *}$ & $52.95 \pm 1.31^{\star \star \star \star}$ & $64.62 \pm 0.70^{\star * \star *}$ \\
\hline$K_{e l}\left(h^{-1}\right)$ & $0.03 \pm 0.016$ & $0.05 \pm 0.02^{\star * \star}$ & $0.065 \pm 0.003^{* * * *}$ & $0.071 \pm 0.08^{\star \star * *}$ \\
\hline $\mathrm{V}_{\mathrm{d}}(\mathrm{L} / \mathrm{kg})$ & $232.56 \pm 64.59$ & $141.99 \pm 12.94^{\star * *}$ & $107.72 \pm 15.74^{\star * \star *}$ & $86.57 \pm 7.04^{\star \star \star \star}$ \\
\hline MRT (hr) & $9.79 \pm 0.279$ & $9.26 \pm 0.12^{* * *}$ & $8.85 \pm 0.10^{\star * \star *}$ & $8.20 \pm 0.19^{* * *}$ \\
\hline
\end{tabular}

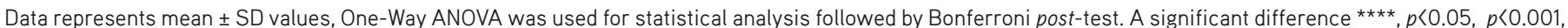

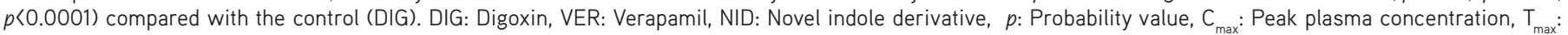

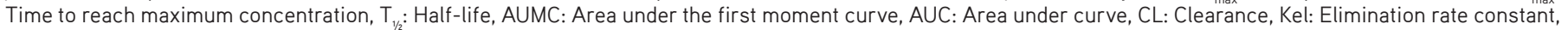
$V_{d}$ : Volume of distribution, MRT: Mean residual time 


\section{DISCUSSION}

In this study, we isolated a new compound from toad skin and spectral data accessed the structure. Some other studies reported different compounds from toad skin, ${ }^{34}$ but this compound was not reported earlier. The MTD was determined according to OECD guidelines and found $5 \mathrm{mg} / \mathrm{kg}$; others reported the $L_{50}$ of TSE as $400 \mathrm{mg} / \mathrm{kg} \cdot{ }^{35}$ In vitro studies proved that NID inhibited P-gp and enhanced the clear permeability of DIG. Some plant extracts have shown P-gp inhibition in in vitro studies, and several studies are reported as P-gp inhibitors. ${ }^{36}$ Few more studies reported that VER increases the oral bioavailability of DIG up to $60 \%$ but reported side effects; ${ }^{37}$ in our study, NID has shown better oral bioavailability of DIG. In a similar study, the compound from the Asiatic toad (Bufo gargarizans) inhibited P-gp and decreased the expression. ${ }^{38}$ Some studies explained that the herbal compounds inhibited P-gp and enhanced the oral bioavailability of its substrate drugs. ${ }^{39}$ A similar study reported that toad parasitoid gland secretion inhibited P-gp and increased the bioavailability of substrate drug. ${ }^{40}$ Our study also achieved P-gp inhibition and improved the bioavailability of DIG with NID.

\section{CONCLUSION}

The isolated compound from Indian toad skin is confined as a NID and unreported earlier; the compound significantly inhibited P-gp mediated transportation. In vivo studies revealed that NID increased the oral bioavailability of DIG. Co-administration of a drug with potent molecules like NID can alter transporter function to improve drug bioavailability.

\section{ACKNOWLEDGMENTS}

Thanks to director National Institute of Nutrition (NIN) - Hyd for formulation and supplying high fat diet; special thanks to Director-Indian Institute of Chemical Technology (IICT)-Hyd, A.Srinivas National Institute of Technology (NIT)-Wgl.

Conflict of interest: No conflict of interest was declared by the authors. The authors are solely responsible for the content and writing of this paper.

\section{REFERENCES}

1. Zhang Y. Why do we study animal toxins? Dongwuxue Yanjiu. 2015;36:183-222.

2. Utkin YN. Animal venom studies: Current benefits and future developments. World J Biol Chem. 2015;6:28-33.

3. Peigneur S, Tytgat J. Toxins in drug discovery and pharmacology. Toxins (Basel). 2018;10:126.

4. Qi J, Tan CK, Hashimi SM, Zulfiker AH, Good D, Wei MQ. Toad glandular secretions and skin extractions as anti-inflammatory and anticancer agents. Evid Based Complement Alternat Med. 2014;2014:312684.

5. Urban MC, Phillips BL, Skelly DK, Shine R. A toad more traveled: the heterogeneous invasion dynamics of cane toads in Australia. Am Nat. 2008;171:E134-E148.
6. Garg A, Hippargi R, Gandhare A. Toad skin-secretions: potent source of pharmacologically and therapeutically significant compounds. Int $\mathrm{J}$ Pharmacol. 2007;5:17.

7. Mills JW, Prum BE. Morphology of the exocrine glands of the frog skin. Am J Anat. 1984;171:91-106.

8. Jared C, Mailho-Fontana PL, Marques-Porto R, Sciani JM, Pimenta DC, Brodie Jr. ED, Antoniazzi MM. Skin gland concentrations adapted to different evolutionary pressures in the head and posterior regions of the caecilian siphonops annulatus. Sci Rep. 2018;1:3576.

9. Toledo RC, Jared C. Cutaneous granular glands and amphibian venom. Comp Biochem Physiol. 1995;1-29.

10. Zhang Y, Yuan B, Takagi N, Wang H, Zhou Y, Si N, Yang J, Wei X, Zhao $\mathrm{H}$, Bian B. Comparative analysis of hydrophilic ingredients in toad skin and toad venom using the UHPLC-HR-MS/MS and UPLC-QqQMS/MS methods together with the anti-inflammatory evaluation of indolealkylamines. Molecules. 2018;24:86.

11. Ramana KV, Singhal SS, Reddy AB. Therapeutic potential of natural pharmacological agents in the treatment of human diseases. BioMed Res Int. 2014;573452.

12. Meng Q, Yau LF, Lu JG, Wu ZZ, Zhang BX, Wang JR, Jiang ZH. Chemical profiling and cytotoxicity assay of bufadienolides in toad venom and toad skin. J Ethnopharmacol. 2016;187:74-82.

13. Sharom FJ. The P-glycoprotein efflux pump: how does it transport drugs? J Membr Biol. 1997;160:161-175.

14. Lin JH, Yamazaki M. Role of P-glycoprotein in pharmacokinetics: clinical implications. Clin Pharmacokinet. 2003;42:59-98.

15. Hoosain FG, Choonara YE, Tomar LK, Kumar P, Tyagi C, du Toit LC, Pillay V. Bypassing P-glycoprotein drug efflux mechanisms: possible applications in pharmacoresistant schizophrenia therapy. Biomed Res Int. 2015;2015:484963.

16. Amin ML. P-glycoprotein inhibition for optimal drug delivery. Drug Target Insights. 2013;7:27-34.

17. Kong XB, Yang ZK, Liang LJ, Huang JF, Lin HL. Overexpression of P-glycoprotein in hepatocellular carcinoma and its clinical implication. World J Gastroenterol. 2000;6:134-135.

18. Kim SW, Md Hasanuzzaman, Cho M, Kim NH, Choi HY, Han JW, Park HJ, Oh JW, Shin JG. Role of 14-3-3 sigma in over-expression of P-gp by rifampin and paclitaxel stimulation through interaction with PXR. Cell Signal. 2017;31:124-134.

19. Lee CA, Cook JA, Reyner EL, Smith DA. P-glycoprotein related drug interactions: clinical importance and a consideration of disease states. Expert Opin Drug Metab Toxicol. 2010;6:603-619.

20. Glaeser H. Importance of P-glycoprotein for drug-drug interactions. Handb Exp Pharmacol. 2011;285-297.

21. Leopoldo M, Nardulli P, Contino M, Leonetti F, Luurtsema G, Colabufo NA. An updated patent review on P-glycoprotein inhibitors (2011-2018). Expert Opin Ther Pat. 2019;29:455-461.

22. Binkhathlan Z, Lavasanifar A. P-glycoprotein inhibition as a therapeutic approach for overcoming multidrug resistance in cancer: current status and future perspectives. Curr Cancer Drug Targets. 2013;13:326-346.

23. Akamine $Y$, Yasui-Furukori N, Uno T. Drug-drug interactions of P-gp substrates unrelated to CYP metabolism. Curr Drug Metab. 2019;20:124-129.

24. Wang L, Sun Y. Efflux mechanism and pathway of verapamil pumping by human P-glycoprotein. Arch Biochem Biophys. 2020;696:108675. 
25. Sasidharan S, Chen Y, Saravanan D, Sundram KM, Yoga Latha L. Extraction, isolation and characterization of bioactive compounds from plants' extracts. Afr J Tradit Complement Altern Med. 2011;8:1-10.

26. Abubakar AR, Haque M. Preparation of Medicinal Plants: Basic extraction and fractionation procedures for experimental purposes. J Pharm Bioallied Sci. 2020;12:1-10.

27. Ottesen JL, Weber A, Gürtler H, Mikkelsen LF. New housing conditions: improving the welfare of experimental animals. Altern Lab Anim. 2004;(Suppl 1B):397-404.

28. Jonsson M, Jestoi M, Nathanail AV, Kokkonen UM, Anttila M, Koivisto P, Karhunen P, Peltonen K. Application of OECD Guideline 423 in assessing the acute oral toxicity of moniliformin. Food Chem Toxicol. 2013;53:27-32.

29. Barthe L, Woodley JF, Kenworthy S, Houin G. An improved everted gut sac as a simple and accurate technique to measure paracellular transport across the small intestine. Eur J Drug Metab Pharmacokinet. 1998;23:313-323.

30. Palumbo P, Picchini U, Beck B, van Gelder J, Delbar N, DeGaetano A. A general approach to the apparent permeability index. J Pharmacokinet Pharmacodyn. 2008;35:235-248.

31. Zou W, Yang Y, Gu Y, Zhu P, Zhang M, Cheng Z, Liu X, Yu Y, Peng X. Repeated blood collection from tail vein of non-anesthetized rats with a vacuum blood collection system. J Vis Exp. 2017:55852.

32. Mathies JC, Austin MA. Modified acetonitrile protein-precipitation method of sample preparation for drug assay by liquid chromatography. Clin Chem. 1980;26:1760.

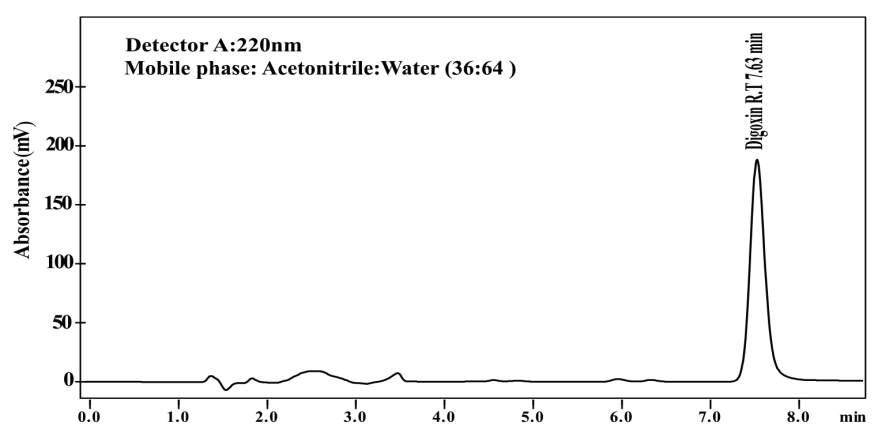

Supplementary Figure 1. Typical chromatogram of digoxin in rat plasma

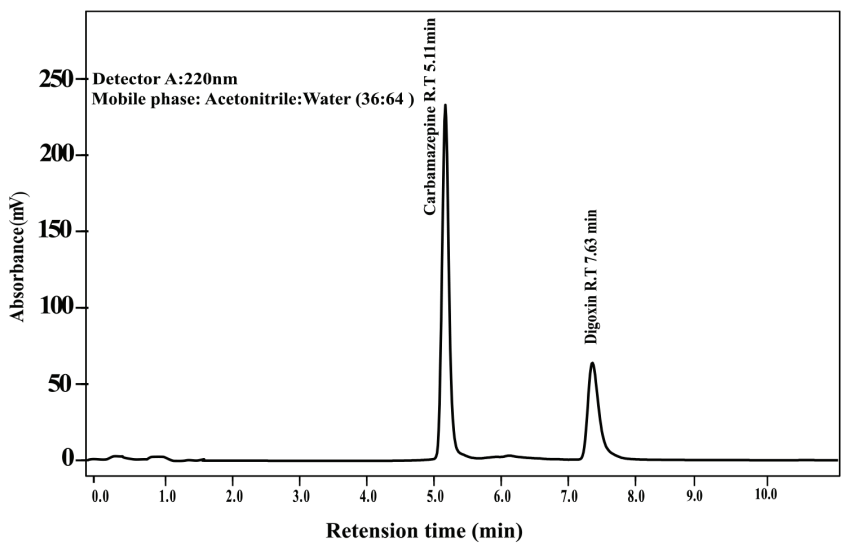

Supplementary Figure 2. Chromatogram of digoxin with internal standard in plasma
33. Amuamuta A, Plengsuriyakarn T, Na-Bangchang K. Anticholangiocarcinoma activity and toxicity of the Kaempferia galanga Linn. Rhizome ethanolic extract. BMC Complement Altern Med. 2017;17:213.

34. Barnhart K, Forman ME, Umile TP, Kueneman J, McKenzie V, Salinas I, Minbiole KPC, Woodhams DC. Identification of bufadienolides from the boreal toad, anaxyrus boreas, active against a fungal pathogen. Microb Ecol. 2017;74:990-1000.

35. Manika D, Auddy B, Gomes A. Pharmacological study of the toad skin extract on experimental animals. Indian J Pharmacol. 1996;2:72-76.

36. Deferme S, Kamuhabwa A, Nshimo C, de Witte P, Augustijns P. Screening of Tanzanian plant extracts for their potential inhibitory effect on P-glycoprotein mediated efflux. Phytother Res. 2003;17:459464.

37. Summers MA, Moore JL, McAuley JW. Use of verapamil as a potential P-glycoprotein inhibitor in a patient with refractory epilepsy. Ann Pharmacother. 2004:38:1631-1634.

38. Yuan Z, Shi X, Qiu Y, Jia T, Yuan X, Zou Y, Liu C, Yu H, Yuan Y, He X, $\mathrm{Xu} \mathrm{K}$, Yin P. Reversal of P-gp-mediated multidrug resistance in colon cancer by cinobufagin. Oncol Rep. 2017;37:1815-1825.

39. Athukuri BL, Neerati P. Enhanced oral bioavailability of domperidone with piperine in male wistar rats: involvement of CYP3A1 and P-gp inhibition. J Pharm Pharm Sci. 2017;20:28-37.

40. Madugula N, Neerati P. Influence of toad parotid gland secretion from Indian toad (Bufo melanostictus) in diabetic rats: an experimental evidence of P-glycoprotein inhibition. Int J Pharm Res. 2020;125-135.

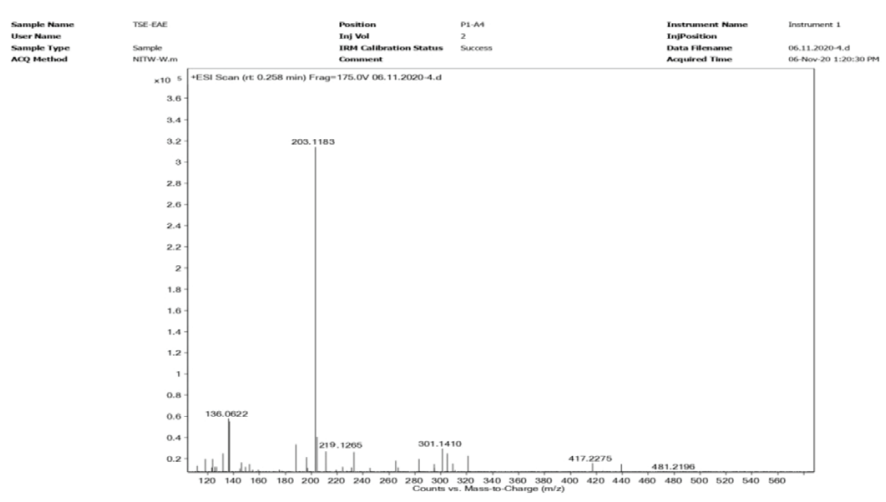

Supplementary Figure 3. LC-MS spectra of NID

LC-MS: Liquid chromatography-mass spectrometry, NID: Novel indole derivative

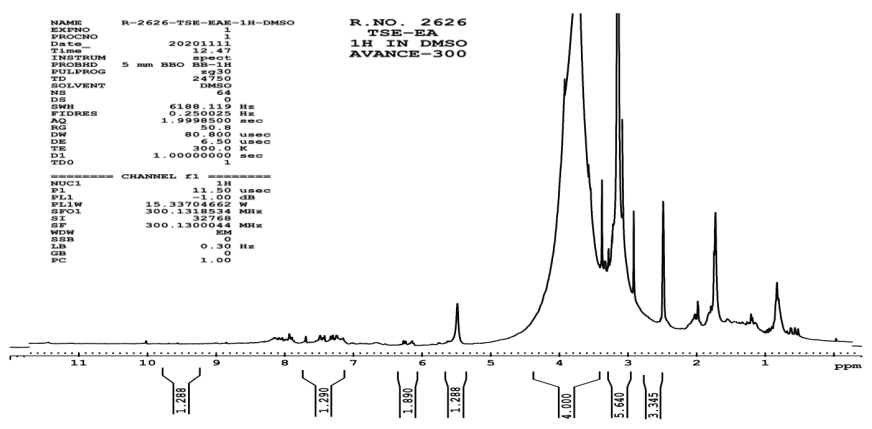

Supplementary Figure 4. ${ }^{1} \mathrm{H}$ NMR spectra of NID

NMR: Nuclear magnetic resonance, NID: Novel indole derivative 

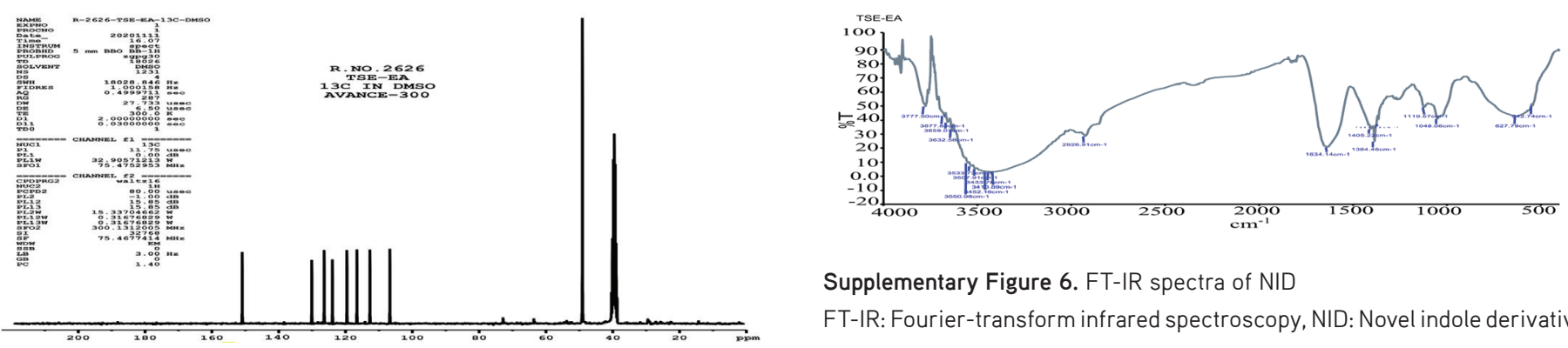

Supplementary Figure 6. FT-IR spectra of NID

FT-IR: Fourier-transform infrared spectroscopy, NID: Novel indole derivative

Supplementary Figure $5 .{ }^{13} \mathrm{C}$ NMR spectra of NID

NMR: Nuclear magnetic resonance, NID: Novel indole derivative

\section{Supplementary Table 1 . Toxicity studies and mortality rate}

\begin{tabular}{llll} 
Group & Treatment & $\begin{array}{l}\text { Sign of } \\
\text { toxicity } \\
\text { (TS/NS) }\end{array}$ & $\begin{array}{l}\text { Mortality } \\
\text { (D/S) }\end{array}$ \\
\hline Control & Saline & $0 / 3$ & $0 / 3$ \\
\hline NID & $5 \mathrm{mg} / \mathrm{kg}$ & $0 / 3$ & $0 / 3$ \\
\hline NID & $50 \mathrm{mg} / \mathrm{kg}$ & $3 / 3$ & $3 / 3$ \\
\hline NID & $300 \mathrm{mg} / \mathrm{kg}$ & $3 / 3$ & $3 / 3$ \\
\hline NID & $2000 \mathrm{mg} / \mathrm{kg}$ & $3 / 3$ & $3 / 3$ \\
\hline
\end{tabular}

$(n=3)$, NID: Novel indole derivative, TS: Toxicity sign, NS: No sign of toxicity,

D: Death, S: Survival, L: Live

\section{Supplementary Table 2. Plasma drug concentrations $(\mu \mathrm{g} / \mathrm{mL})$ of digoxin at different time points}

\begin{tabular}{lllll}
\multirow{2}{*}{ Time $(\mathrm{h})$} & $\mathrm{DIG}$ & $\mathrm{DIG}+\mathrm{VER}$ & $\mathrm{DIG}+\mathrm{NID} 2 \mathrm{mg} / \mathrm{kg}$ & $\mathrm{DIG}+\mathrm{NID} 4 \mathrm{mg} / \mathrm{kg}$ \\
\cline { 2 - 5 } & Mean \pm SD & Mean \pm SD & Mean \pm SD & Mean \pm SD \\
\hline 0 & $0.0 \pm 0.0$ & $0.0 \pm 0.0$ & $0.0 \pm 0.0$ & $0.0 \pm 0.0$ \\
\hline 0.5 & $1.226 \pm 0.160$ & $1.85 \pm 0.078$ & $2.666 \pm 0.081$ & $3.716 \pm 0.172$ \\
\hline 1 & $2.393 \pm 0.231$ & $3.236 \pm 0.213$ & $3.391 \pm 0.100$ & $4.576 \pm 0.040$ \\
\hline 2 & $3.265 \pm 0.253$ & $3.793 \pm 0.116$ & $4.596 \pm 0.096$ & $7.476 \pm 0.186$ \\
\hline 6 & $2.65 \pm 0.187$ & $3.183 \pm 0.081$ & $4.08 \pm 0.295$ & $4.88 \pm 0.414$ \\
\hline 8 & $2.228 \pm 0.336$ & $2.65 \pm 0.063$ & $3.6 \pm 0.057$ & $3.78 \pm 0.261$ \\
\hline 12 & $1.343 \pm 0.089$ & $1.868 \pm 0.044$ & $2.743 \pm 0.265$ & $3.18 \pm 0.078$ \\
\hline 24 & $1.293 \pm 0.116$ & $1.235 \pm 0.057$ & $1.416 \pm 0.0496$ & $1.73 \pm 0.144$ \\
\hline
\end{tabular}

Data represents mean \pm SD values. DIG: Digoxin, VER: Verapamil, NID: Novel indole derivative, SD: Standard deviation 